\title{
Technology Entrepreneurship of Large State-Owned Firms in Emerging Economies
}

\author{
Jing Ge, Management School, Jilin University, Changchun, China \\ Hongxia Sun, Management School, Jilin University, Changchun, China \& Suzhou University of Science and Technology, \\ Suzhou, China \\ Yong Chen, Texas A\&M International University, Laredo, USA
}

\begin{abstract}
Firms in emerging economies face greater resource constraints and higher levels of firm informality than those in developed economies. Particularly, large state-owned firms struggle for survival when encountering intense competition in the changing domestic markets and the global market. Technology entrepreneurship is proved an effective approach for these firms to gain competitive advantages. However, because large firms are less innovative and less adaptable, they often fail in technology entrepreneurship. As such, this article proposes a four-step scheme for large state-owned firms to develop technology entrepreneurship strategies and to implement entrepreneurial activities. A case study of the FAW Group Corporation, a Chinese automobile manufacturer, is conducted to elaborate the proposed scheme.
\end{abstract}

\section{KEYWORDS}

Emerging Economies, Entrepreneurship, State-Owned Firms, Technology Entrepreneurship

\section{INTRODUCTION}

In today's knowledge-based economy, entrepreneurship is a driver for innovation and competition (Gorji \& Rahimian, 2011). Because entrepreneurship can stimulate positive outcomes for firms and societies (Duane Ireland \& Webb, 2007), it is a key driving force in the economic development of a country (Carree \&Thurik, 2003; Gupta, MacMillan, \& Surie, 2004). On one hand, entrepreneurship can facilitate firms in product, process, and administrative innovation (Covin \& Miles, 1999; Schumpeter, 2010). It not only facilitates strategic renewal in firms (Hitt, Nixon, Hoskisson, \& Kochhar, 1999), but also creates values for customers and wealth for shareholders (Hitt, Ireland, Camp, \& Sexton, 2001). On the other hand, entrepreneurship contributes to societies by creating jobs (Birley, 1986), promoting technological progress and the revitalization of economies (Birley, 1986; Zahra, 1996), and shaping global cultures (Gudeman, 1992; Inglehart \& Baker, 2000). Therefore, entrepreneurship is a means of contributing to employment as well as social and political stability (Sarri \& Trihopoulou,2005).

Janson and Wrycza (1999) point out that there is a positive association between the use of information technologies and firms' entrepreneurial activities. Information technologies can be 
applied for creating customer value, improving organizational effectiveness, and managing business risk (Janson \& Wrycza, 1999). Some innovative technologies have brought benefits to businesses, including big data, artificial intelligence, blockchain, and Internet of Things (IoT) (Furtado et al 2017; Hassani et al 2018; Ivanov 2019; Ivanov, Borisova, and Muminova 2019; Li et al 2018; Lu 2018a,2018b, 2019; Oliverio 2018; Viriyasitavat, Anuphaptrirong, Hoonsopon, 2019; Viriyasitavat and Hoonsopon 2019; Xu et al 2014; Xu and Duan 2019). Particularly, as the next generation of communication infrastructure and economic tide after computer and the Internet, IoT is expected to bring a revolution in society by boosting a tremendous amount of innovation, efficiency, and quality (Bi, Xu, \& Wang, 2014; He, Lo, Xie, \& Lartigue, 2016; Viriyasitavat, Xu, Bi, Hoonsopon, Charoenruk, 2019; Weyrich \& Ebert, 2016; Xu 2011; Xu \& Viriyasitavat, 2019; Xu, Xu, Li 2018).

Technology entrepreneurship is different from mainstream entrepreneurship because it focuses on new opportunities through innovation in science and engineering (Shane \&Venkataraman, 2003; Beckman, Eisenhardt, Kotha, Meyer, \& Rajagopalan, 2012). According to Bailetti (2012), technology entrepreneurship is "an investment in a project that assembles and deploys specialized individuals and heterogeneous assets that are intricately related to advances in scientific and technological knowledge for the purpose of creating and capturing value for a firm" (p9). It is an effective approach for growth, differentiation, and competitive advantage at the firm, regional, and national levels (Bailetti, 2012).

Technology entrepreneurship is not about the general management practices used to operate small businesses. Instead, firms of all sizes can use technology to create, deliver, and capture value for their stakeholders via technology entrepreneurship (Bailetti, 2012). Technology entrepreneurship is closely linked to technological innovation, emerging markets, and the creation of new products (Ferreira, Ferreira, Fernandes, Jalali, Raposo, \& Marques, 2016). Compared with small firms, large firms (with 500 or more employees) rely less on information technologies (McWilliams, 1995), but are easier to be fettered by bureaucracy and expensive existing information systems (Covin \& Slevin, 1989; Douglas, Craig, \& Keegan, 1982; Pelham \& Wilson, 1995). Large firms are less innovative, less adaptable, and often fail in technology entrepreneurship due to their slow response times to new technologies and consumers' needs (Carroll, 1984) as well as their hostile environments for creative ideas (Burgelman, 1983).

Business opportunities arise across the world because political, social, and economical change occur in many other countries (Janson \& Wrycza, 1999). In recent years, emerging economies are playing a growing role in the world's economy (Siqueira \& Bruton, 2010). They are characterized by high levels of taxation, government corruption, and difficulty in registering a new business (Peng, 2000). Due to greater resource constraints and higher levels of firm informality in emerging economies, technology entrepreneurship takes place in a context very different from that of developed economies (Siqueira \& Bruton, 2010). In some emerging economies, such as China, central-planned economies are transforming into market-oriented ones (Janson \& Wrycza, 1999). Large state-owned firms struggle for survival when encountering intense competition in domestic market and the global market, where technique update accelerates and information expanding becomes fast. Accordingly, technology entrepreneurship becomes an effective approach for these firms to gain competitive advantages. This paper proposes a scheme for large state-owned firms to develop technology entrepreneurship strategies. In specific, this scheme has four steps, namely establishing a desiderative vision, encouraging innovation, building entrepreneurship atmosphere inside a firm, and building entrepreneurship team. Further, a case study of FAW, a leading automobile manufacturer in China, is conducted to elaborate the proposed scheme.

\section{LITERATURE REVIEW}

\section{Entrepreneurship}

The concept of entrepreneurship is not new in academia and industry. However, there is no consensus in the definition of entrepreneurship (Hou et al 2018). Scholars think entrepreneurship as an eclectic 
phenomenon and examine it by adopting theories and methods from multiple disciplines, including accounting, anthropology, economics, finance, management, marketing, operations management, political science, psychology, and sociology (Duane Ireland, \& Webb, 2007). Entrepreneurship has been studied via diverse perspectives, such as opportunity orientation (Barreto, 2012; Shane \& Venkataraman, 2000), resource orientation (Barney, 1991), culture (Hornsby, Kuratko, \& Zahra, 2002), learning (Polits, 2005), and social network (Singh, 2001). Essentially, entrepreneurship is a concept in management. Therefore, some scholars define entrepreneurship through the lens of management. For example, Morris and Sexton (1996) define entrepreneurship as the process of creating value through the management of resources to take advantage of an opportunity. Lumpkin and Dess (1996) note that entrepreneurship is the process through which new products, new processes, and new markets are created. Morris (1998) thinks that entrepreneurship is a process which intermingles with other processes or events in organizations and society. Thornton (1999), however, defines entrepreneurship as the creation of new organizations. Chua, Chrisman, and Sharma (1999) point out that entrepreneurship are acts of organizational creation, renewal, or innovation, which occur within or outside an existing organization. Shane and Venkataraman (2000) define entrepreneurship as the process of discovering, evaluating, and exploiting opportunities.

Entrepreneurship is a kind of ability with which an individual or an organization choose a goal and find or assemble the necessary resource to achieve it in innovative or unusual ways (Schumpeter, 2010). It requires innovatively changing the pattern of resource deployment and capabilities to add new possibilities for positioning in markets (Stopford \& Baden-Fuller, 1994). As a complex disequilibrium process, entrepreneurship involves identification of market opportunity, risk taking, proactiveness, innovativeness, and creation of combinations of resources (Chiles, Tuggle, McMullen, Bierman, \& Greening, 2010; Kirzner, 1973; Knight, 2001; Miller, 1983; Schumpeter, 2010). Studies have found a positive association between entrepreneurship and firms' expansion of strategic activities (Miller \& Friesen, 1984), and between entrepreneurship and firms' performance (Covin \& Slevin, 1991; Miller \& Friesen, 1984; Snow \& Hrebiniak, 1980). Particularly, corporate entrepreneurship can extend firms' competitive advantages through internally generated innovations that alter the balance of competition within an industry or create entirely new industries (Ferreira, 2002). It is a key means for firms to achieve competitive advantages by accumulating, converting, and leveraging resources (Floyd \& Wooldridge, 1999). In specific, corporate entrepreneurship rejuvenates or redefines firms via product, process, and administrative innovations (Covin \& Miles, 1999).

Entrepreneurship has been examined by scholars at the levels of individual, firm, and society (Duane Ireland \& Webb, 2007). At the individual level, entrepreneurship is thought as the action of entrepreneurs, individuals who bring about an improvement for other individuals and for societies (Gorji \& Rahimian, 2011). Entrepreneurs are self-confident and persistent in accomplishing their aims with great energy and commitment (Schmitt-Rodermund, 2004). They are risk takers, who seek profit opportunities and introduce new combinations or innovations (Van Praag, 1999).

New business venturing is usually associated with individual entrepreneurship (Stopford \& Baden-Fuller, 1994). At the firm level, entrepreneurship involves the diffusion of firms' competencies and the extension of opportunities through the evolution of their internally generated resources (Covin \& Slevin, 1991). Entrepreneurship requires firms to be proactive, innovative, and risktaking (Covin \& Slevin, 1991). Firms' entrepreneurial activities rely on their risk-taking propensity, tendency to act in competitively aggressive, proactive manners, as well as frequent and extensive product innovation (Slevin \& Covin, 1990). Some labels describe the organizational processes and the strategies when firms act entrepreneurially, including entrepreneurial posture (Covin \& Slevin, 1991), entrepreneurial orientation (Lumpkin \& Dess, 1996), entrepreneurial style (Naman $\&$ Slevin, 1993), and entrepreneurship (Miller, 1983). Studies on entrepreneurship has followed two directions: opportunity exploitation and resource exploitation (Ge, Sun, Chen, \& Gao, 2016). The former is a typical activity in entrepreneurship, including opportunity identification, assessment, and utilization (Shane \& Venkataraman, 2000), whereas the latter is a process in which firms integrate 
their resources and improve their abilities by finding business opportunities on their own in order to achieve competition advantages via creating values for customers (Sirmon, Gove, \& Hitt, 2008). Resource exploitation consists of resource identification, acquisition, integration, and utilization (Cai \& Liu, 2007; Sirmon, Hitt, Ireland, \& Gilbert, 2011).

\section{Technology Entrepreneurship}

Technology entrepreneurship is a combination of entrepreneurship and technology-based innovation (Ferreira, Ferreira, Fernandes, Jalali, Raposo, \& Marques, 2016). It is characterized by the collaborative experimentation and production of new products, assets, and their attributes (Bailetti, 2012). Essentially, technology entrepreneurship is a type of entrepreneurship aiming to exploit opportunities related to advances in science and engineering (Beckman, Eisenhardt, Kotha, Meyer, \& Rajagopalan, 2012). It involves searching for a particular technology, launching new ventures, introducing new applications, and exploiting opportunities that rely on scientific and technical knowledge (Bailetti, 2012).

Technology entrepreneurship is a multi-dimensional concept that involves many actors and different levels of analysis (Garud \& Karnøe, 2003). Giones and Brem (2017) note that technology entrepreneurship should be examined from three perspectives, namely the underlying technological opportunity, the entrepreneurship process, and the resource acquisition. Bailetti (2012) identifies four elements of technology entrepreneurship: (1) The ultimate outcomes of technology entrepreneurship are value creation and capture; (2) Value is created and captured for firms through projects that combine specialists and assets to produce and adopt technology. Individuals with special skills and capabilities work together, exploring and exploiting scientific and technological change to benefit firms. (3) Investment is the mechanism mobilized to create and capture value; (4) The individuals involved in a project influence and are influenced by advances in relevant scientific and technology knowledge. The four elements indicate that technology entrepreneurship can facilitate prosperity in individuals, firms, regions, and nations (Bailetti, 2012). For individuals, they are embedded in the technology path they try to shape in real time (Garud \& Karnøe, 2003). Each of them has unique role and responsibility in collaboration toward accomplishing shared goals (Lindenberg \& Foss, 2011). For firms, technology entrepreneurship can help them assemble specialized individuals and heterogeneous assets for the purpose of creating and capturing value through collaborative exploration and experimentation (Bailetti, 2012). Firms can use technology to create, deliver, and capture value for their stakeholders via technology entrepreneurship (Bailetti, 2012). For countries, particularly emerging economies, technology entrepreneurship can help them attract investments in productive technologies and talent (Bailetti, 2012).

\section{Technology Orientation}

Technology orientation means a firm's proactivity in developing new technologies as well as new ideas and using them in new product development ( $\mathrm{Li}, 2005)$. It refers to a firm's openness to new ideas and its propensity to adopt new technologies (Hurley \& Hult, 1998). Technology orientation reflects a firm's values and beliefs about managerial actions and resource allocation (Noble, Sinha, $\&$ Kumar, 2002). It makes it easier for firms to access new ideas, to adopt new methods and advanced technologies (Zhou, Yim, \& Tse, 2005), and to perform organizational renewal (Li, 2005).

Technology orientation is reflected by a firm's investment in research and development, its use of sophisticated technologies in product innovation, and its integration of new technologies (Slater, Hult, \& Olson, 2007). Technology-oriented firms focus on generating new ideas and adopting new methods as well as the most advanced technologies (Zhou, Yim, \& Tse, 2005). They are knowledge intensive and stress the importance of sharing and applying technical knowledge (Chen, Tang, Jin, $\mathrm{Xie}, \& \mathrm{Li}, 2014)$. Accordingly, technology-oriented firms foster cooperation, promote creativity, and improve employees' motivation (Cavusgil, Zou, \& Naidu, 1993; Eyal \& Kark, 2004). In addition, technology-oriented firms emphasize developing and improving their products (Chen, Tang, Jin, 
Xie, \& Li, 2014). Furthermore, because technology-oriented firms are more open to new ideas, new methods, and changes, they can easily perform organizational renewal, such as reorganization and redefinition of their business concepts and implementing system-wide changes. As a result, problems caused by outdated production systems or operational inefficiency can be easily found (Li, 2005). Technology-oriented firms provide a more favorable environment for technology entrepreneurship. Usually, technology-oriented firms are more likely to perform technology entrepreneurship than non-technology-oriented firms are.

\section{A Scheme For Developing Technology Entrepreneurship}

Emerging economies focus on developing their domestic high-technology industries. However, they will not follow the same patterns as firms in developed economies (Siqueira \& Bruton, 2010). The greater resource constraints and higher levels of firm informality in emerging economies drive firms take different technology entrepreneurship. In emerging economies, the success of entrepreneurship depends on how to initiate entrepreneurship spirit within a firm, and how to make sure the innovation and entrepreneurship activities can shape the atmosphere of the firm. Accordingly, four steps should be followed to develop entrepreneurship strategies, namely establishing a desiderative vision, encouraging innovation, building entrepreneurship atmosphere inside a firm, and building entrepreneurship team.

\section{Step 1: Establishing a Desiderative Vision}

Entrepreneurship roots in the creative ability of employees. Therefore, a desiderative vision should be well understood by employees. Figure 1 shows the process of sharing a desiderative vision among employees.

Figure 1. The process of sharing a desiderative vision among employees

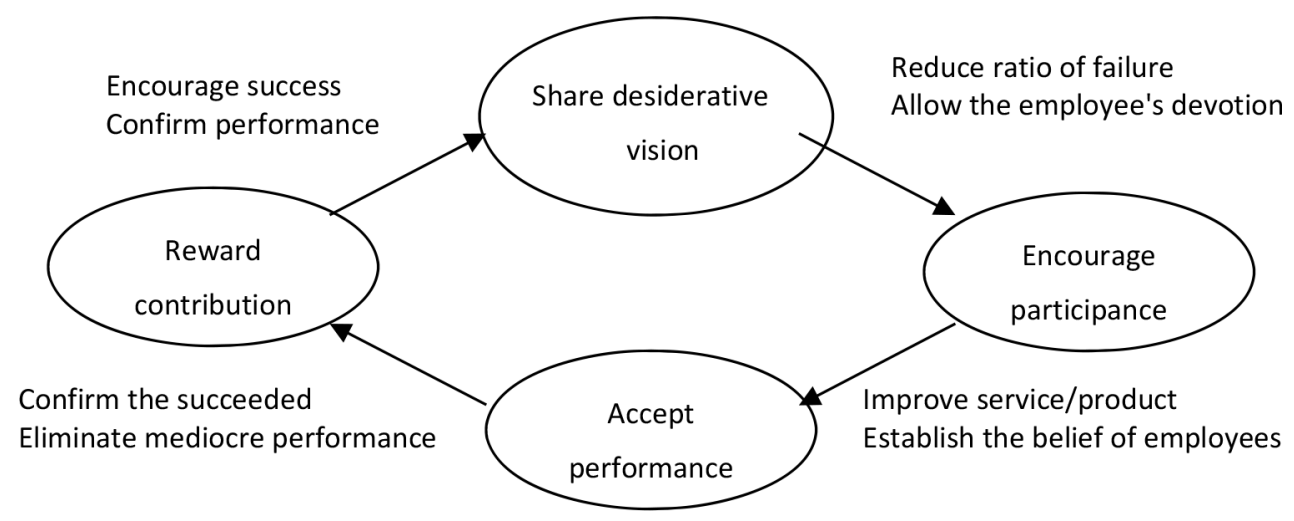

The direction of entrepreneurship can be grasped when it starts. Through well communication, employees will know well about the goals of entrepreneurship. Once the desiderative vision is shared, solid foundation for entrepreneurship is built. The shared vision will reinforce employee beliefs and encourage them to fulfil the goals.

\section{Step 2: Encouraging Innovation}

Innovation is a special tool for intrapreneurs. Therefore, firms should comprehend and develop innovation from the perspectives of key strategic factors. Some scholars think that innovation is disordered and cannot be planned, whereas other scholars argue that innovation is a kind of system 
method. In fact, the two views are both reasonable, because they comprehend the hypostasis of innovation differently.

There are two types of innovation, namely radical innovation and gradual innovation. Radical innovation has been applied in practice and has got breakthrough progress. It still needs testing, so it should not be managed. But radical innovation must be understood and cultivated. Gradual innovation is an evolutionary process, in which products or services are put into a newer or bigger market system. Usually, after a radical innovation brings a scientific breakthrough, a gradual innovation will begin (see Figure. 2), and is affected by firm structure, marketing strategies, financing system, and other formal systems.

\section{Figure 2. Radical innovation and gradual innovation}

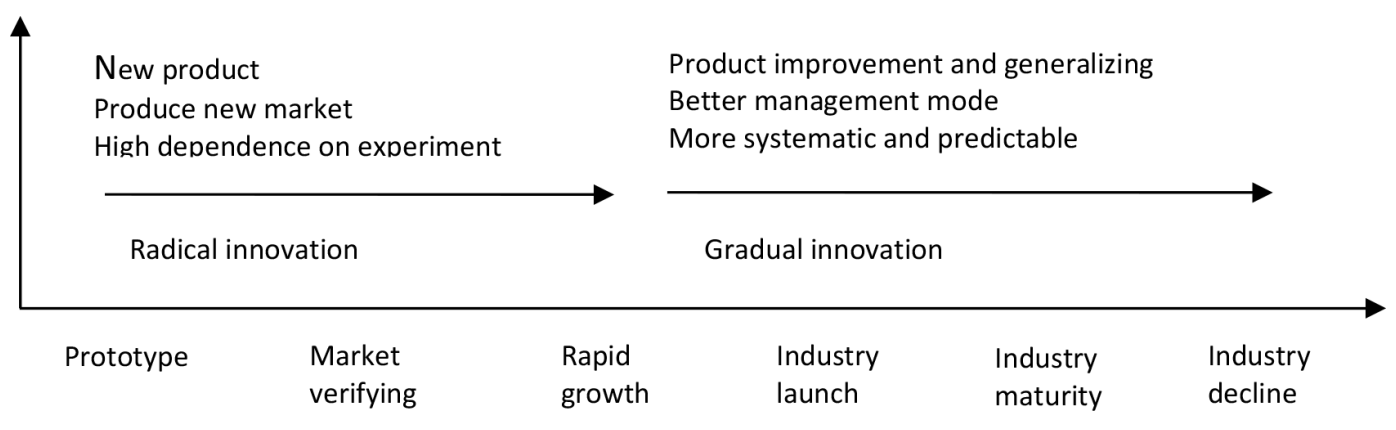

\section{Step 3: Building Entrepreneurship Atmosphere Inside a Firm}

In order to implement entrepreneurship, employees should be venture undertaking developers. It is necessary to invest the role of capital in entrepreneurial activities. Hisrich (1990) notes that firms need to develop activities that can better bring up employees and promote information sharing when exploiting employees' ability as the origin of firms' innovation. Other than establishing entrepreneurship mode and promoting intrapreneurs, firms should build an atmosphere that facilitates creation among employees. Attention to innovation from the top management will not only promote employees to perform innovation, but also help the implementation of innovation projects. A favorable environment for entrepreneurship can be built via implementing entrepreneurial activities, such as trainings on entrepreneurship and evaluation of entrepreneurship.

Figure 3 indicates the common functions of the individual and organizational factors affecting entrepreneurship. To implement innovations needed by entrepreneurship, firms should pay attention to the combination of individual attitude, value view, behavior direction, organization structure, and encouragement factors. In addition, firm should build an innovation friendly environment to support employees' entrepreneurial activities.

\section{Step 4: Building an Entrepreneurship Team}

An entrepreneurship team is a small group that exploits originality in a semi-independent mode. This team is different from other groups who deal with daily activities, because it has comparatively independent budget and an uncontrolled leader who can make decisions based on main guidelines. In this way, the team will not sink into the procedures that hinder entrepreneurial activities. Sometimes the leader of the team is called a product winner or an intrapreneur. The team might be called a small firm that operates inside a large firm. Inside the entrepreneurship team, an individuals' skills are integrated into a collective innovation ability. Members learn from each other and each one makes progress steadily. Everyone's progress combines and move firms' entrepreneurship forward. 
Figure 3. The common functions of the individual and organizational factors

Individual factors

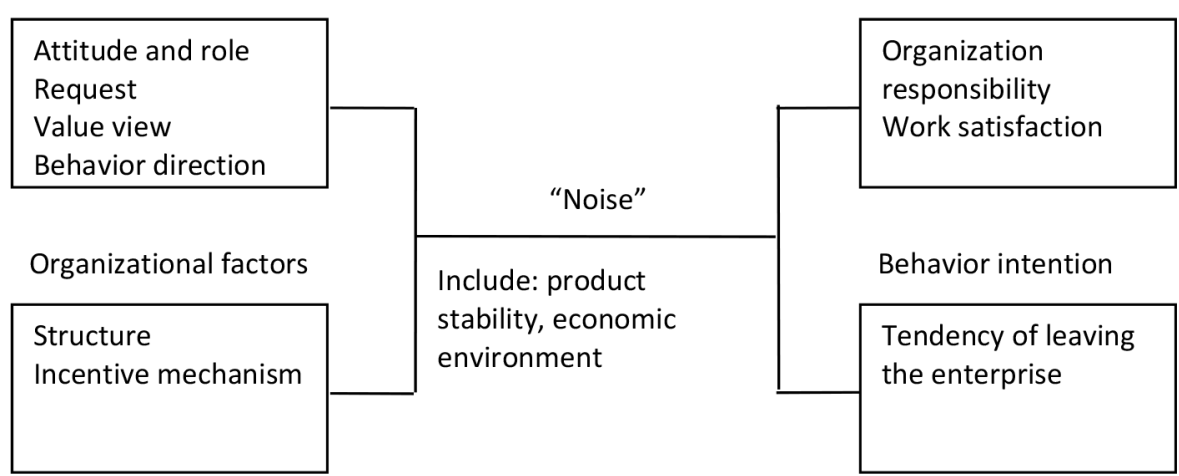

\section{METHODOLOGY}

Case study is an effective method to explore and verify theories because it can easily capture and follow up new phenomena in management practice (Eisenhardt, 1989; Yin, 2009). As an empirical research method, case study can answer questions related to why and how (Stake, 2000; Yin, 1994) and further explore the answers to the question what should be. In addition, due to its requirement in globality, case study encourages researchers to analyze in depth the interaction mechanism among each part of certain unknown objects/events (Sturman, 1994) so that researchers can contribute to theory development by conducting case studies (Mao \& Li, 2011).

\section{Case Study}

FAW Group Corporation, also known as the First Automobile Manufactory, was built on July 15 in 1953. This is a milestone in Chinese automobile industry. Starting from manufacturing medium trucks, FAW has a diverse product lines now, including heavy trucks, medium trucks, light trucks, and sedans. In the past six decades, FAW has played a vital role in Chinese automobile industry.

\section{Phase I (1953-1978)}

Starting from 1953, more than 20,000 excellent cadres and skilled workers worked on building the factory of FAW. All the constructers shared a desiderative vision and work extensively hard to build the factory. It took only three years to complete the construction with high quality and to make the production line ready. When FAW made the first medium truck in 1956, the first chapter of Chinese automobile industry started. In 1978, FAW's product types rose to three. Its productivity jumped from 30,000 to 60,000 . Around one thousand ameliorations had been applied to the model CA10. More than 70 new models had been developed. Meanwhile, FAW trained large number of workers and sent parts of its workers to build other projects for Chinese automobile industry as well as some China-aid foreign project. The success of entrepreneurship in FAW at this phase relies on the vision communion.

\section{Phase II (1979-1988)}

In this period, FAW focused on diversifying its product lines. Particularly, it adopted the close joint management mode of the four factories in Jilin and Changchun. In addition, FAW strengthened its cooperation with the Automobile Research Institute and the Ninth Design Academy to improve R\&D. Furthermore, FAW learned advance technique and management from Japanese automobile manufacturers. When upgrading its product lines, FAW continuously conducted technique reformation 
and adopted new approaches and techniques, such as simultaneity project and network. These efforts made FAQ get a new lease of life.

\section{Phase III (1989-2001)}

FAW adjusted its product lines in this period focusing on developing light trucks and passenger cars. Its product lines included heavy trucks, medium trucks, light trucks, and sedans. The proportion of sedans exceeded that of trucks in FAW's total production. Meanwhile, the unitary state-owned asset structure of FAW diversified. Building joint venture with Volkswagen, FAW improved its capability in producing sedans. In this period, the most important innovation in FAW was the Double Orbit System. One orbit is to build a production base with a yearly output of 30,000 for middle-class and high-class sedans by adopting the technique absorption mode. The new generation of Hongqi, FAW's own brand, is the product for this base. The other orbit is to build a joint venture with Volkswagen to manufacture economic and high-class sedans at an annual output of 150,000. The Double Orbit System not only allows FAW to develop its own brand, but also bridges FAW with foreign markets. Other than the domestic markets, FAW explored markets oversea and sold products in more than 70 countries and areas.

In 1993, FAW built the technique center by integrating the original automobile research institute, the factory design institute, the automobile material research institute, the craft material research institute, the electronic computing center, the mold center, and the technique department. This center greatly increases FAW's technique innovation ability and shortens its new production development period. To gain competitive advantages, FAW implemented the quality total war, neatened internal economic order, pushed the accurate producing mode, centralized purchase, and enhanced management. Most important, FAW implemented Project 801 and 901 for reserve of talents. FAW built a talent pool of 20,000 professionals. It worked with Saint Leo University and Holland Maastricht School of Management to build partnership with their MBA programs. FAW also sends employees to domestic universities and oversea firms for training. During this period, the strategic factors of entrepreneurship were synthetically and successfully applied in FAW. In addition, the functions of every factor were fully exerted. Multifunctional entrepreneurship teams were built. Innovation activities were encouraged. The entrepreneurship vision was fully shared by employees. Therefore, the favorable atmosphere for entrepreneurship formed. At the end of this period, FAW had 341 types of products. Its total assets increased to 53.3 billion Yuan. Its profits rose 31 times.

\section{Phase IV (2002-present)}

In 2002, FAW set its five-year goals as achieving sales in millions, digitization in administration, and internationalization in management. In 2016, the production and sale of automobile in FAW reached 3.15 million. Its sales reached 400 billion Yuan. The cooperation between FAW and Volkswagen, Toyota, and Mazda went well.

\section{DISCUSSION}

The case of FAW indicates that: (1) entrepreneurship is internal activities for firms; (2) entrepreneurship needs authorization and resource guarantee; (3) firms should encourage employees to be entrepreneurs; (4) intrapreneurs translate creative thoughts into profitable results.

FAW's success depends on its predominant innovation ability, the tough down-to-earth spirit of the intrapreneurs, the favorable entrepreneurship atmosphere, and the concrete incentive mechanism. In Phase I, the vision communion was well shared by all employees. Particularly, Chinese people at that time valued spiritual pursuit. Once the constructors and the employees knew the goals, they devoted themselves to the factory. Their entrepreneurial activities helped China start its automobile industry. During the construction, the construction team had strong creative ability with high efficiency. The technical team had poor innovation ability because they only applied the existing oversea techniques. 
When the construction was done, the vision communion became weaker. As a result, entrepreneurial activities were deficient. In addition, due to the deficiency of external economy environment and out of date internal management, entrepreneurship condition in FAW was not favorable. Entrepreneurship teams were not active.

In Phase II, entrepreneurship strategy factors were adopted better by FAW. Compared with Phase I, the vision communion was not that strong. It was implemented in some units only, not the entire firm. FAW took many measures to encourage innovations. Accordingly, many breakthroughs in techniques were achieved. In order to build favorable entrepreneurship environment, FAW not only absorbed advance oversea techniques, but also cooperated with automobile research and design institutes. In this way, FAW also developed specialized technique entrepreneurship teams.

In Phase III, FAW made great progress in integrating the entrepreneurship strategy factors. The vision communion was shared across FAW, including accessorial factories. The vision was even promoted as slogan in advertisement. Moreover, FAW took various measures to encourage innovations. As a result, technical innovation was accelerated and many breakthroughs in techniques were achieved. In addition, FAW adopted measures, such as the Talent Development Strategy, to build entrepreneurship environment. Many entrepreneurship teams were built and provided strong support for innovation in FAW.

Overall, FAW implemented entrepreneurship strategies successfully in the three phases. However, improvements are still needed. At present, because people's beliefs and value have changed, measures other than propaganda and education should be adopted to let employees share the desiderative development vision across the firm. Moreover, training and incentive mechanism are not effective in evoking employees' enthusiasm in entrepreneurship any longer. Advanced management should be adopted to build entrepreneurship environment and to encourage entrepreneurial activities. Particularly, a set of integrated entrepreneurship environment building mechanism should also be established. In addition, unitary technical entrepreneurship teams and simple studying institutes do not meet the requirements of modern firms. Entrepreneurship teams that can perform research should be developed to achieve competitive advantages in global markets.

\section{CONCLUSION}

With the development of economic globalization, firms rely more on innovation for surviving in fierce international competition. They implement technology entrepreneurship to explore and exploit opportunities, which help them create and capture value. In recent years, emerging economies play increasing role in world economy. Firms in emerging economies implement different technology entrepreneurship due to greater resource constraints and higher levels of firm informality. As the central-planned economy is changing into market-oriented one in China, large state-owned firms encounter intense market competition. How FAW implemented entrepreneurship strategy can provide reference for large state-owned firms in emerging economies. Phase I is a special era and FAW is the product of this era. In Phase II, FAW gradually implemented production innovation by changing its unitary producing mechanism. FAW successfully expanded its product lines from medium trucks to passenger cars. The success of FAW's entrepreneurship in Phase II is related with the market environment in China. The reforming and opening policy started in 1979. FAW took full advantage of the market opportunities brought by the new policy. It adjusted its product lines in responding to the changes of social environment, political environment, and economic environment. FAW's entrepreneurship strategy in this phase helped it keep the leading position in techniques, talent, and management in Chinese automobile industry.

In Phase III, FAW implemented comprehensive reform in its system and operation by following the trend of reform among state-owned firms in China. Particularly, FAW is traded on stock market. It also dropped some non-core operations. In order to gain more domestic market share, FAW built branches in important economic areas across China. In addition, FAW realized that joint 
ventures and cooperation with other firms are helpful for gaining and maintaining its strengths global market. Therefore, FAW implemented internationalization strategy by cooperating with Volkswagen and Toyota.

When FAW implemented its entrepreneurship strategies, it encountered problems, especially disadvantages of its location. Compared with its competitors, such as Shanghai Automotive Industry corporation (SAIC) and Dongfeng Motor Corporation (DMC), the location of FAW causes disadvantages in price and equipment cost because its suppliers are far away in southern China. In order to reduce the disadvantages, FAW built branches in Tianjin, Dalian, Qingdao and other coastal cities. This strategy helped FAW take advantage of the favorable business environment in coastal areas.

Although FAW has achieved great successes in implementing its entrepreneurship strategy, challenges still exist. The first challenge comes from FAW's management system. Even though FAW has performed reform for a long time, only adjustments were taken, and the original management system, which has strong political characteristic, is still running. Because FAW is not a pure firm, its political characteristic causes high product cost and frequent employee turnover. Compared with large firms in Europe, America and Japan, FAW's management system and techniques are still out of date. The second challenge comes from FAW's domestic rival SMIC. Although SMIC is newer than FAW, it locates in Shanghai, which brings advantages in policy, capital, technique, talent, and management. These advantages support SMIC in market completion. The sales of SMIC has surpassed that of FAW recently. The third challenge comes from some private automobile firms, including Beiqi Foton Motor Corporation, Southeast Motor Corporation, and Chery Motor Corporation. These private firms have gained market shares in automobile industry and put great pressure on cost for FAW.

FAW implemented some strategic measures to deal with these challenges. The changing market requires large state-owned firms to adopt completely new management systems, not just revising exiting systems. Meanwhile, entrepreneurial activities should be taken all the time to develop new techniques and products. Only in this way, consumers' need can be met well. This is the solution for large stateowned firms to gain competitive advantages in domestic market and even in the global market. At present, new technologies, such as big data, artificial intelligence, blockchain, and IoT, are available. Firms should take advantage of these new technologies to implement technology entrepreneurship. 


\section{REFERENCES}

Bailetti, T. (2012). Technology entrepreneurship: overview, definition, and distinctive aspects. Technology Innovation Management Review, 2(2).

Barney, J. (1991). Firm resources and sustained competitive advantage. Journal of Management, 17(1), 99-120.

Barreto, I. (2012). Solving the entrepreneurial puzzle: The role of entrepreneurial interpretation in opportunity formation and related processes. Journal of Management Studies, 49(2), 356-380.

Beckman, C., Eisenhardt, K., Kotha, S., Meyer, A., \& Rajagopalan, N. (2012). Technology entrepreneurship. Strategic Entrepreneurship Journal, 6(2), 89-93.

Bi, Z., Xu, L., \& Wang, C. (2014). Internet of things for enterprise systems of modern manufacturing. IEEE Transactions on Industrial Informatics, 10(2), 1537-1546.

Birley, S. (1986). The role of new firms: Births, deaths and job generation. Strategic Management Journal, 7(4), 361-376.

Burgelman, R. A. (1983). A process model of internal corporate venturing in the diversified major firm. Administrative Science Quarterly, 223-244.

Cai, L., \& Liu, Q. (2007). The resource integration model in new ventures. Science of Science and Management of Science and Technology, 28(2), 95-102.

Carree, M. A., \& Thurik, A. R. (2010). The impact of entrepreneurship on economic growth. In Handbook of entrepreneurship research (pp. 557-594). New York, NY: Springer.

Carroll, G. R. (1984). The specialist strategy. California Management Review, 26(3), 126-137.

Cavusgil, S. T., Zou, S., \& Naidu, G. M. (1993). Product and promotion adaptation in export ventures: An empirical investigation. Journal of International Business Studies, 24(3), 479-506.

Chen, Y., Tang, G., Jin, J., Xie, Q., \& Li, J. (2014). CEO s' transformational leadership and product innovation performance: The roles of corporate entrepreneurship and technology orientation. Journal of Product Innovation Management, 31, 2-17.

Chiles, T. H., Tuggle, C. S., McMullen, J. S., Bierman, L., \& Greening, D. W. (2010). Dynamic creation: Extending the radical Austrian approach to entrepreneurship. Organization Studies, 31(1), 7-46.

Chua, J. H., Chrisman, J. J., \& Sharma, P. (1999). Defining the family business by behavior. Entrepreneurship Theory and Practice, 23(4), 19-39.

Covin, J. G., \& Miles, M. P. (1999). Corporate entrepreneurship and the pursuit of competitive advantage. Entrepreneurship Theory and Practice, 23(3), 47-63.

Covin, J. G., \& Slevin, D. P. (1989). Strategic management of small firms in hostile and benign environments. Strategic Management Journal, 10(1), 75-87.

Covin, J. G., \& Slevin, D. P. (1991). A conceptual model of entrepreneurship as firm behavior. Entrepreneurship Theory and Practice, 16(1), 7-26.

Douglas, S. P., Craig, C. S., \& Keegan, W. J. (1982). Approaches to assessing international marketing opportunities for small-sized and medium-sized companies. The Columbia Journal of World Business, 17(3), 26-32.

Duane Ireland, R., \& Webb, J. W. (2007). A cross-disciplinary exploration of entrepreneurship research. Journal of Management, 33(6), 891-927.

Eisenhardt, K. M. (1989). Building theories from case study research. Academy of Management Review, 14(4), $532-550$.

Eyal, O., \& Kark, R. (2004). How do transformational leaders transform organizations? A study of the relationship between leadership and entrepreneurship. Leadership and Policy in Schools, 3(3), 211-235.

Ferreira, J. (2002). Corporate entrepreneurship: A strategic and structural perspective. International Council for Small Business, 47, 16-19. 
Ferreira, J. J., Ferreira, F. A., Fernandes, C. I., Jalali, M. S., Raposo, M. L., \& Marques, C. S. (2016). What do we [not] know about technology entrepreneurship research? The International Entrepreneurship and Management Journal, 12(3), 713-733.

Floyd, S. W., \& Wooldridge, B. (1999). Knowledge creation and social networks in corporate entrepreneurship: The renewal of organizational capability. Entrepreneurship Theory and Practice, 23(3), 123-144.

Furtado, L., Dutra, M., \& Macedo, D. (2017). Value Creation in Big Data Scenarios: A Literature Survey. Journal of Industrial Integration and Management, 2(1), 1750002.

Garud, R., \& Karnøe, P. (2003). Bricolage versus breakthrough: Distributed and embedded agency in technology entrepreneurship. Research Policy, 32(2), 277-300.

Ge, B., Sun, Y., Chen, Y., \& Gao, Y. (2016). Opportunity exploitation and resource exploitation: An integrative growth model for entrepreneurship. Internet Research, 26(2), 498-528.

Giones, F., \& Brem, A. (2017). Digital technology entrepreneurship: A definition and research agenda. Technology Innovation Management Review, 7(5).

Gorji, M. B., \& Rahimian, P. (2011). The study of barriers to entrepreneurship in men and women. Australian Journal of Business and Management Research, 1(9), 31.

Gudeman, S. (1992). Remodeling the house of economics: Culture and innovation. American Ethnologist, 19(1), 141-154.

Gupta, V., MacMillan, I. C., \& Surie, G. (2004). Entrepreneurial leadership: Developing and measuring a crosscultural construct. Journal of Business Venturing, 19(2), 241-260.

Hassani, H., Huang, X., \& Silva, E. (2018). Banking with blockchain-ed big data. Journal of Management Analytics, 5(4), 256-275. doi:10.1080/23270012.2018.1528900

He, J., Lo, D. C. T., Xie, Y., \& Lartigue, J. (2016, October). Integrating Internet of Things (IoT) into STEM undergraduate education: Case study of a modern technology infused courseware for embedded system course. In Proceedings of the 2016 IEEE Frontiers in Education Conference (FIE) (pp. 1-9). IEEE Press.

Hisrich, R. D. (1990). Entrepreneurship/intrapreneurship. The American Psychologist, 45(2), 209.

Hitt, M. A., Ireland, R. D., Camp, S. M., \& Sexton, D. L. (2001). Guest editor's introduction to the special issue strategic entrepreneurship. Strategic Management Journal, 22(6/7), 479-492.

Hitt, M. A., Nixon, R. D., Hoskisson, R. E., \& Kochhar, R. (1999). Corporate entrepreneurship and crossfunctional fertilization: Activation, process and disintegration of a new product design team. Entrepreneurship Theory and Practice, 23(3), 145-168.

Hornsby, J. S., Kuratko, D. F., \& Zahra, S. A. (2002). Middle managers' perception of the internal environment for corporate entrepreneurship: Assessing a measurement scale. Journal of Business Venturing, 17(3), 253-273.

Hou, F., Ge, B., \& Su, Y. (2018). Review of Classical Intention-Based Entrepreneurial Models and Construction of Framework from Combined Perspectives of Entrepreneurial Motivation and Cognition. Journal of Industrial Integration and Management, 3(3), 1850012.

Hurley, R. F., \& Hult, G. T. M. (1998). Innovation, market orientation, and organizational learning: An integration and empirical examination. Journal of Marketing, 62(3), 42-54.

Inglehart, R., \& Baker, W. E. (2000). Modernization, cultural change, and the persistence of traditional values. American Sociological Review, 19-51.

Ivanov, L.A. (2019). Establishment of technological startups based on research and development. Nanotehnologii v stroitel'stve [Nanotechnologies in Construction], 11(2), 207-216. doi:10.15828/2075-8545-2019-11-2-207-216

Ivanov, LA., Borisova, O.N., \& Muminova, S.R. (2019). The inventions in nanotechnologies as practical solutions Part I. Nanotehnologii v stroitel'stve [Nanotechnologies in Construction], 11(1), 91-101. doi:10.15828/20758545-2019-11-1-91-101

Janson, M. A., \& Wrycza, S. (1999). Information technology and entrepreneurship: Three cases from Poland. International Journal of Information Management, 19(5), 351-367. 
Knight, G. A. (2001). Entrepreneurship and strategy in the international SME. Journal of International Management, 7(3), 155-171.

Li, J. J. (2005). The formation of managerial networks of foreign firms in China: The effects of strategic orientations. Asia Pacific Journal of Management, 22(4), 423-443.

Li, S., Xu, L., \& Zhao, S. (2018). 5G Internet of Things: A Survey. Journal of Industrial Information Integration, 10, 1-9. doi:10.1016/j.jii.2018.01.005

Lu, Y. (2018a). Blockchain and the related issues: A review of current research topics. Journal of Management Analytics, 5(4), 231-255. doi:10.1080/23270012.2018.1516523

Lu, Y. (2018b). Blockchain: A Survey on Functions, Applications and Open Issues. Journal of Industrial Integration and Management, 3(4), 1850015.

Lu, Y. (2019). Artificial intelligence: A survey on evolution, models, applications and future trends. Journal of Management Analytics, 6(1), 1-29. doi:10.1080/23270012.2019.1570365

Lindenberg, S., \& Foss, N. J. (2011). Managing joint production motivation: The role of goal framing and governance mechanisms. Academy of Management Review, 36(3), 500-525.

Lumpkin, G. T., \& Dess, G. G. (1996). Clarifying the entrepreneurial orientation construct and linking it to performance. Academy of Management Review, 21(1), 135-172.

Mao, J. Y., \& Li, X. Y. (2011). The role of theory in case study. Management World, 2, 106-113.

McWilliams, B. (1995). Information Entrepreneurs. Computerworld, 29(24), 20-25.

Miller, D. (1983). The correlates of entrepreneurship in three types of firms. Management Science, 29(7), 770-791.

Miller, D., \& Friesen, P. H. (1984). A longitudinal study of the corporate life cycle. Management Science, $30(10), 1161-1183$.

Morris, M. H. (1998). Entrepreneurial intensity: Sustainable advantages for individuals, organizations, and societies. Westport, CT: Quorum Books.

Morris, M. H., \& Sexton, D. L. (1996). The concept of entrepreneurial intensity: Implications for company performance. Journal of Business Research, 36(1), 5-13.

Naman, J. L., \& Slevin, D. P. (1993). Entrepreneurship and the concept of fit: A model and empirical tests. Strategic Management Journal, 14(2), 137-153.

Noble, C. H., Sinha, R. K., \& Kumar, A. (2002). Market orientation and alternative strategic orientations: A longitudinal assessment of performance implications. Journal of Marketing, 66(4), 25-39.

Oliverio, J. (2018). A Survey of Social Media, Big Data, Data Mining, and Analytics. Journal of Industrial Integration and Management, 03(03), 1850003.

Pelham, A. M., \& Wilson, D. T. (1999). Does market orientation matter for small firms? In Developing a market orientation (pp. 167-194). Sage Publications.

Peng, M. W. (2000). Business strategies in transition economies. Thousand Oaks, CA: Sage.

Politis, D. (2005). The process of entrepreneurial learning: A conceptual framework. Entrepreneurship Theory and Practice, 29(4), 399-424.

Sarri, K., \& Trihopoulou, A. (2005). Female entrepreneurs' personal characteristics and motivation: A review of the Greek situation. Women in Management Review, 20(1), 24-36.

Schmitt-Rodermund, E. (2004). Pathways to successful entrepreneurship: Parenting, personality, early entrepreneurial competence, and interests. Journal of Vocational Behavior, 65(3), 498-518.

Schumpeter, J. A. (2010). Capitalism, socialism and democracy. Routledge.

Shane, S., \& Venkataraman, S. (2000). The promise of entrepreneurship as a field of research. Academy of Management Review, 25(1), 217-226. 
Shane, S., \& Venkataraman, S. (2003). Guest editors' introduction to the special issue on technology entrepreneurship. Research Policy, 32(2), 181-184.

Singh, R. P. (2001). A comment on developing the field of entrepreneurship through the study of opportunity recognition and exploitation. Academy of Management Review, 26(1), 10-12.

Siqueira, A. C. O., \& Bruton, G. D. (2010). High-technology entrepreneurship in emerging economies: Firm informality and contextualization of resource-based theory. IEEE Transactions on Engineering Management, 57(1), 39-50.

Sirmon, D. G., Gove, S., \& Hitt, M. A. (2008). Resource management in dyadic competitive rivalry: The effects of resource bundling and deployment. Academy of Management Journal, 51(5), 919-935.

Sirmon, D. G., Hitt, M. A., Ireland, R. D., \& Gilbert, B. A. (2011). Resource orchestration to create competitive advantage breadth, depth, and life cycle effects. Journal of Management, 37(5), 1390-1412.

Slater, S. F., Hult, G. T. M., \& Olson, E. M. (2007). On the importance of matching strategic behavior and target market selection to business strategy in high-tech markets. Journal of the Academy of Marketing Science, $35(1), 5-17$.

Slevin, D. P., \& Covin, J. G. (1990). Juggling entrepreneurial style and organizational structure. MIT Sloan Management Review, 31(2), 43.

Snow, C. C., \& Hrebiniak, L. G. (1980). Strategy, distinctive competence, and organizational performance. Administrative Science Quarterly, 317-336.

Stake, R. E. (2000). Case studies. In N. K. Denzin \& Y. S. Lincoln (Eds.), Handbook of qualitative research (pp. 435-453). Thousand Oaks: Sage.

Stopford, J. M., \& Baden-Fuller, C. W. (1994). Creating corporate entrepreneurship. Strategic Management Journal, 15(7), 521-536.

Sturman, A. (1994). Case study methods. In J. P. Keeves (Ed.), Educational Research, Methodology and Measurement: An International Handbook. Oxford: Pergamon.

Thornton, P. H. (1999). The sociology of entrepreneurship. Annual Review of Sociology, 25(1), 19-46.

Van Praag, C. M. (1999). Some classic views on entrepreneurship. De Economist, 147(3), 311-335.

Viriyasitavat, W., \& Hoonsopon, D. (2019). Blockchain characteristics and consensus in modern business processes. Journal of Industrial Information Integration, 13, 32-39.

Viriyasitavat, W., Anuphaptrirong, T., \& Hoonsopon, D. (2019). When blockchain meets Internet of Things: Characteristics, challenges, and business opportunities. Journal of Industrial Information Integration, 15. doi:10.1016/j.jii.2019.05.002

Viriyasitavat, W., Xu, L., Bi, Z., Hoonsopon, D., \& Charoenruk, N. (2019). Managing QoS of Internetof-Thing Services using Blockchain. IEEE Transactions on Computational Social Systems., doi:10.1109/ TCSS.2019.2919667

Weyrich, M., \& Ebert, C. (2015). Reference architectures for the internet of things. IEEE Software, 33(1), 112-116.

Xu, L. (2011). Enterprise Systems: State-of-the-Art and Future Trends. IEEE Transactions on Industrial Informatics, 7(4), 630-640. doi:10.1109/TII.2011.2167156

Xu, L., \& Duan, L. (2019). Big Data for Cyber Physical Systems in Industry 4.0: A Survey. Enterprise Information Systems, 13(2), 148-169.

Xu, L., He, W., \& Li, S. (2014). Internet of Things in Industries: A Survey. IEEE Transactions on Industrial Informatics, 10(4), 2233-2248. doi:10.1109/TII.2014.2300753

Xu, L., \& Viriyasitavat, W. (2019). Application of Blockchain in Collaborative Internet-of-Things Services. IEEE Transactions on Computational Social Systems., doi:10.1109/TCSS.2019.2913165

Xu, L., Xu, E., \& Li, L. (2018). Industry 4.0: State of the Art and Future Trends. International Journal of Production Research, 56(8), 2941-2962. 
Yin, R. K. (1994). Case study research: design and methods (2nd ed.). Thousand Oaks, CA: Sage.

Yin, R. K. (2009). Case study research: Design and methods (4th ed.). Thousand Oaks, CA: SAGE.

Zahra, S. A. (1996). Governance, ownership, and corporate entrepreneurship: The moderating impact of industry technological opportunities. Academy of Management Journal, 39(6), 1713-1735.

Zhou, K. Z., Yim, C. K., \& Tse, D. K. (2005). The effects of strategic orientations on technology-and marketbased breakthrough innovations. Journal of Marketing, 69(2), 42-60.

Jing Ge is a Ph.D. candidate at the School of Management, Jilin University. Her research interest is in the area of entrepreneurship.

Sun is a professor at the School of Management, Jilin University, Suzhou University of Science and Technology. Her research interest is in the area of entrepreneurship.

Yong Chen is an Assistant Professor in A. R. Sanchez, Jr. School of Business, Texas A\&M International University. He received his Ph.D. from Old Dominion University in Virginia. His research interests are Internet of Things, Big Data, Blockchain, social media, mobile payment, and e-business. 